\title{
Economic Recovery Through Community Empowerment to Reduce Impact of the Covid-19
}

\author{
Sukiyani \\ Universitas Pembangunan Nasional Veteran Yogyakarta, Indonesia \\ e-mail:kiki_sukiyani85@gmail.com
}

\begin{abstract}
The impact of the Covid-19 Pandemic Disaster is still very much felt by the economy of the people in the Special Region of Yogyakarta. The purpose of this research is to map the policies of the Provincial Government of the Special Region of Yogyakarta in empowering the community to the perpetrators of cooperative activities, micro, small and medium enterprises and to map the operational strategies carried out for the development of these policies. This study uses qualitative methods and uses secondary data from various kinds of literature such as books, articles, related journals regarding empowerment policies for actors in cooperative activities, micro, small and medium enterprises from the impact of the Covid-19 pandemic. The data analysis technique used in this research is descriptive analysis. The results of the research, it is known that the success of community empowerment policies for actors in cooperative activities, micro, small and medium enterprises in the Special Region of Yogyakarta from the impact of the Covid-19 pandemic disaster in the first quarter of 2021 experienced growth compared to the first quarter of 2020. The biggest contribution to economic growth in the Special Region of Yogyakarta in the first quarter of 2021 is the information and communication business field.
\end{abstract}

Keywords: Disaster, Covid-19 pandemic, Economi, Special Region of Yogyakarta

\section{ABSTRAK}

Dampak Bencana Pandemi Covid-19 masih sangat dirasakan oleh perekonomian masyarakat di Daerah Istimewa Yogyakarta. Tujuan dari penelitian ini adalah untuk memetakan kebijakan Pemerintah Provinsi Daerah Istimewa Yogyakarta dalam pemberdayaan masyarakat kepada pelaku kegiatan koperasi, usaha mikro, kecil dan menengah serta memetakan strategi operasional yang dilakukan untuk pengembangan usaha tersebut. Penelitian ini menggunakan metode kualitatif dan menggunakan data sekunder dari berbagai macam literatur seperti buku, artikel, jurnal terkait mengenai kebijakan pemberdayaan bagi pelaku kegiatan koperasi, usaha mikro, kecil dan menengah dari dampak 
pandemi Covid-19. Teknik analisis data yang digunakan dalam penelitian ini adalah analisis deskriptif. Hasil penelitian diketahui bahwa keberhasilan kebijakan pemberdayaan masyarakat bagi pelaku kegiatan koperasi, usaha mikro, kecil dan menengah di Daerah Istimewa Yogyakarta dari dampak bencana pandemi Covid-19 pada triwulan I tahun 2021 mengalami pertumbuhan dibandingkan triwulan I tahun 2020. Kontribusi terbesar terhadap pertumbuhan ekonomi Daerah Istimewa Yogyakarta pada triwulan I tahun 2021 adalah bidang usaha informasi dan komunikasi.

Kata kunci: Bencana; Pandemik covid-19, Ekonomi, dan Daerah Istimewa Yogyakarta

\section{INTRODUCTION}

The Covid-19 pandemic has had an impact on the economic sector in all provinces in Indonesia (Susilawati, Falefi, \& Purwoko, 2020) and (Pakpahan, 2020), one of which is the Province of the Special Region of Yogyakarta. The implementation of restrictions on community activities in Indonesia as an effort to handle the Covid-19 pandemic disaster has caused significant economic losses both nationally and in the Province of the Special Region of Yogyakarta (Hadiwardoyo, 2020).

Cooperatives, Micro, Small and Medium Enterprises are one of the ones experiencing the biggest impact on the economy in the Special Region of Yogyakarta caused by several factors, namely a decrease in the number of sales due to a decrease in the number of requests by partners by delaying product purchases and at the same time other actors Cooperative activities, Micro, Small and Medium Enterprises have difficulty getting raw materials and the price of raw materials has also increased so they have to reduce the number of workers (Prasetyo \& Huda, 2019) and make production capacity decrease which results in obstacles in production which ultimately experience capital difficulties and experience cash flow problems (Febrantara, 2020).

The Provincial Government of the Special Region of Yogyakarta which has the authority to carry out economic recovery in the Special Region of Yogyakarta is expected to provide facilities to increase public consumption in the Special Region of Yogyakarta, one of the efforts to reduce the risk of the Covid-19 disaster in the economic sector is through the empowerment of cooperatives, micro, small businesses and middle school in the Special Region of Yogyakarta.

According to Government Regulation of the Republic of Indonesia Number 7 of 2021 concerning Ease, Protection, and Empowerment of Cooperatives and Micro, Small, and Medium Enterprises, what is meant by Cooperatives is a business entity consisting of one person or a legal entity of Cooperatives by basing their activities on the principles of Cooperatives as well as a people's economic movement based on the principle of kinship (Abidin, 2015). Micro Enterprises are productive businesses owned by individuals and or individual business entities that meet the criteria for Micro Enterprises. Small Business is a productive economic business that stands alone, which is carried out by individuals or business entities that are not subsidiaries or not branches of companies that are owned, controlled, or become part of either directly or indirectly from Medium Enterprises or large businesses that meet the criteria for Small Businesses. Medium Enterprises are productive economic businesses that stand alone, which are carried out by individuals or business 
entities that are not subsidiaries or branches of companies that are owned, controlled, or become part of either directly or indirectly with Small Businesses or large businesses that meet the criteria for Medium Enterprises. Micro, Small, and Medium Enterprises are grouped based on the criteria for working capital or annual sales results. The criteria for working capital as referred to in paragraph (1) consist of: Micro Enterprises having a business capital of up to a maximum of Rp. 1,000,000,000.00 (one billion rupiah) excluding land and buildings for business premises; Small Business has a business capital of more than Rp. 1,000,000,000.00 (one billion rupiah) up to a maximum of Rp5.000.000.000,00 (five billion rupiahs) excluding land and buildings for business premises; and Medium Enterprises have a business capital of more than Rp. 5,000,000,000.00 (five billion rupiah) up to a maximum of Rp. 10,000,000,000.00 (ten billion rupiah) excluding land and buildings for business premises.

The criteria for annual sales results consist of: Micro-enterprises having annual sales of up to a maximum of Rp. 2,000,000,000.00 (two billion rupiah); Small Business has annual sales of more than Rp. 2,000,000,000.00 (two billion rupiah) up to a maximum of Rp. 15,000,000,000.00 (fifteen billion rupiah); and Medium Enterprises have annual sales of more than Rp. 15,000,000,000.00 (fifteen billion rupiahs) up to a maximum of Rp. 50,000,000,000.00 (fifty billion rupiahs).

\section{METHODS}

This study used descriptive qualitative methods by utilizing secondary data derived from various literatures such as books, articles, related journals regarding the policy of empowerment and strengthening of Cooperatives, Micro, Small and Medium Enterprises from the impact of the Covid-19 pandemic disaster. The use of descriptive qualitative methods aims to provide a description and get a clear picture that is useful for answering the formulation of the problem, namely about how the policies of the Yogyakarta Special Region Government in saving Cooperatives, Micro, Small and Medium Enterprises from the impact of the COVID-19 pandemic disaster and what strategies are being implemented. can be done for the development of Cooperatives, Micro, Small and Medium Enterprises in the Special Region of Yogyakarta.

\section{RESULTS AND DISCUSSION}

\subsection{The Impact of the Pandemic on Cooperatives, Micro, Small and Medium Enterprises in the Special Region of Yogyakarta}

The impact of the Covid-19 Pandemic disaster experienced by Cooperatives, Micro, Small and Medium Enterprises, among others, there was a decline in sales due to reduced community activities with the Enforcement of Restrictions on Community Activities so that Micro, Small, and Medium Business actors had difficulty obtaining capital due to declining sales levels., the existence of product distribution barriers due to restrictions on the movement of product distribution in certain areas, the difficulty of raw materials because Micro, Small and Medium Enterprises activities depend on the availability of raw materials from other industrial sectors (Febrantara, 2020).

\subsubsection{Efforts of the Provincial Government of the Special Region of Yogyakarta}

The Indonesian government needs to make various efforts to help the community's economy through various policies (Susilawati et al., 2020). The success of the government's policy is highly 
dependent on the support of the components of business actors in the community. The community and the government must jointly protect the economy from the impact of Covid-19 (Hanoatubun, 2020). The policies of the Provincial Government of the Special Region of Yogyakarta in dealing with the impact of the Covid-19 disaster on the activities of Cooperatives, Micro, Small and Medium Enterprises in the Special Region of Yogyakarta through the Office of Cooperatives and Small and Medium Enterprises, are as follows:

(1) Economic Recovery Through Empowerment of Cooperatives, Micro, Small and Medium Enterprises in the New Normal Era, among others: Strengthening the Capacity of Cooperatives, Micro, Small and Medium Enterprises by surviving, striving, creative and innovative. First, human Resources Empowerment, access to capital; IT-based online marketing, fulfillment of raw materials, production stability, regulatory support, value development with business vision transformation, bussines checkups, partnerships and mutual cooperation, team management. Second, adapting to market conditions, business opportunities, consumer behavior, and being flexible to changes. Third, creating social \& economic resilience in the region in the face of the Covid-19 pandemic disaster, by suppressing the spread of the Covid-19 Pandemic so that the economy rises (Recovery Economy), realizing social resilience in the new normal era. Fourth, regulation of Cooperatives, Micro, Small and Medium Enterprises by correcting data through the SIBAKUL application, conducting a survey of the impact of covid on Cooperatives, Micro, Small and Medium Enterprises, making Procedures \& Standard Operating Procedures for the New Normal Era on Cooperatives, Micro, Small and Medium Enterprises activities, and socializing Standard Operating Procedures. Fifth, acceleration of Cooperatives, Micro, Small and Medium Enterprises by partnering with online markets, Free Shipping subsidies, Cooperative Assistance, Micro, Small and Medium Enterprises, Interest subsidies and credit facilities, Media campaigns, loan restructuring. Sixth, cooperative Adjustment, Micro, Small and Medium Enterprises Virtual Q-RIS (Quick Response Code Indonesian Standard), On-line business, on-line Cooperative Annual Member Meeting, On-line training, On-line market, Transaction security.

(2) Revitalizing the People's Economy through the Development of the "Sibakul" Application, namely: First, recovery of Cooperatives, Micro, Small and Medium Enterprises by providing access to capital, markets or markets, product competitiveness, digital technology, business strategies, corporation culture or partnerships. Second, data Update, Supervision, Online Annual Member Meeting, Modern Cooperative. Second, Free-shipping Markethub, Cooperative Product Curation, Micro, Small and Medium Enterprises, Local Resources, Business Product Quality Digital, Customer Orientation, Marketing Strategy, Business Cooperation Product Identity. Third, recovery, Ease of Reorientation, Development. Fourth, supply Chains, Business Processes. MarketHub, Market Place, Market Oriented, Branding. Fifth, the development of the "Sibakuljogja" application in an integrated manner by fostering Cooperatives, Micro, Small and Medium Enterprises, namely by monitoring and evaluating through coaching records on the profile of Cooperatives, Micro, Small and Medium Enterprises in the "SibakulJogja" application.

(3) Initiating the Village Preneur Program is a village or sub-district that has the ability to stimulate the dynamics of economic entrepreneurship based on potential and local wisdom, through business units to be managed to be of global quality by strengthening community capacity in a sustainable manner (Kemenkop-UKM, 2018; Burhan, F., 2020). 


\subsection{Operational Strategy in the Recovery and Strengthening of Cooperatives and Small and Medium Enterprises}

The recovery and strengthening of MSME policies is carried out by increasing synergies between programs and between government institutions (Hadiwardoyo, 2020). The Operational Strategy of the Provincial Government of the Special Region of Yogyakarta in dealing with the impact of the Covid-19 disaster on the activities of Cooperatives, Micro, Small and Medium Enterprises in the Special Region of Yogyakarta through the Office of Cooperatives and Small and Medium Enterprises, among others: (1) Handling Management by conducting Valid Data Management, Regulatory Facilitation, Promotion, Coaching, Online/Offline Training \& Assistance, Networking, Online Marketing, Partnership Cooperation, Investors, Distributors, Suppliers, Cooperative Development, Micro, Small and Medium Enterprises, Acceleration, Publication, Promotion. (2) Involving Multi Stakeholders, namely Central Government, Local Government, Private, Academics, Community, Media, Society. (3) Capacity Building on Raw Materials by maintaining Availability, Supply, Production, Product Design, Stock Management, Curation, providing access to capital (Turnover, Profit, Loan Restructuring, Ease of Credit), Strengthening human resources through competency improvement, Member Participation, and Health Protocol. (4) Marketing with Supply, Distribution, Digital Marketing, Virtual and Offline Exhibitions.

Regulatory support with the Decree of the Governor of the Special Region of Yogyakarta and the Circular Letter of the Governor of the Special Region of Yogyakarta concerning the Purchase of Cooperative Products and Small and Medium Enterprises. The policies that have been carried out by the Provincial Government of the Special Region of Yogyakarta in dealing with the impact of the Covid-19 disaster on the activities of Cooperatives, Micro, Small and Medium Enterprises in the Special Region of Yogyakarta through the Office of Cooperatives and Small and Medium Enterprises, are as follows:

First, Cross-Sectoral \& Cross-Authority Synergy by assisting with Pre-Employment Card Registration, Facilitating the Registration of Cooperatives and Small and Medium Enterprises Prospective Banpres Recipients Earning Rp 2.4 million, Partnerships with Corporate Social Responsibility/Partnership Programs and Community Development/Private/Owned Enterprises Countries Related to Empowerment of Small and Medium Enterprises, Partnering with online marketplace applications such as Gojek, Grab, Tokopedia, Jogjakita, Whatsapp Business for Marketplace Development, Encouraging Cooperatives and Small and Medium Enterprises to Get Affordable Credit Assistance by Banks Through the National Economic Recovery Scheme, Exemption of Rent Fees for Products of Cooperatives and Small and Medium Enterprises at the Gallery and Small and Medium Enterprises at Yogyakarta Airport Internasional Airport, Optimizing Field Work Practice Students as Customer Service Free Shipping for seven days a week. (1) Improvement of Cooperatives and Small and Medium Enterprises Development Scheme Development of the "Sibakul Jogja" Application as a Marketplace, by Disseminating Health Protocols to Small, Micro and Medium Enterprises in Strategic Locations, Tiered Training for Small, Micro and Medium Enterprises Affected by the Pandemic, Dissemination of the Indonesian Quick Response Code Standard for Small, Micro and Medium Enterprises to Increase Digital Transactions, Online Registration of Cooperatives and Small and Medium Enterprises Through the "Sibakul" application to obtain Training Package Facilities, Issuance of Travel Certificates for Cooperatives and Small and Medium 
Enterprises whose Operational Areas are Outside the Special Region of Yogyakarta. (2) Market Dynamics by Providing Marketing Stimulus for Small and Medium Business Products through Free Shipping, Making Pottery Masks \& Sinks through Empowerment of Small and Medium Enterprises, Development of Virtual Small and Medium Enterprises Exhibition, Dissemination of Circular Letter of the Governor of the Special Region of Yogyakarta Number 519/7669 concerning Purchase of Business Products Small and Medium Enterprises, Encouraging Online Marketing for Cooperatives and Small and Medium Enterprises Through Existing Marketplaces. (3) Initiating and developing Preneur Village.

\section{CONCLUSION}

Based on the results of the study, the success of the community empowerment policy for the perpetrators of cooperative activities, micro, small and medium enterprises in the Special Region of Yogyakarta from the impact of the Covid-19 pandemic that the economy in the Special Region of Yogyakarta in the first quarter of 2021 experienced growth compared to the first quarter of 2020. The biggest contribution to economic growth in the Special Region of Yogyakarta in the first quarter of 2021 is the information and communication business field.

The activities of Cooperatives, Micro, Small and Medium Enterprises in the Special Region of Yogyakarta are experiencing the impact of the Covid-19 Pandemic Disaster, namely Decrease in Sales, Difficulty in Capital, Barriers to Product Distribution, and Difficulty in Raw Materials. The Provincial Government of the Special Region of Yogyakarta has made efforts to empower and strengthen the community involved in the activities of Cooperatives, Micro, Small and Medium Enterprises in the Special Region of Yogyakarta by conducting a Survey of Cooperatives, Micro, Small and Medium Enterprises affected by the Covid-19 pandemic, providing purchasing power stimulus to the community through the free shipping program, building partnerships in marketing and promotion, revitalizing the "Sibakul-Jogja" application into a Marketplace/Markethub, initiating Virtual Exhibitions, On-Line Businesses, Non-Cash Transactions, Assistance for Cooperatives, Micro, Small and Medium Enterprises routinely, carry out an inventory of financing for Cooperatives, Micro, Small and Medium Enterprises (easy installments, and free of income tax), Empowering Cooperatives, Micro, Small and Medium Enterprises in supporting the handling of Covid-19 (Making masks, Personal Protective Equipment, Handwashing Places, etc.), Pre-Employment Card Assistance, Su Facilitation rat Information on Business Networks for Cooperatives, Micro, Small and Medium Enterprises and Socialization of Standard Operating Procedures regarding Health Protocols in the New Normal era for the activities of Cooperatives, Micro, Small and Medium Enterprises.

\section{REFERENCES}

Abidin, M. (2015). Kebijakan Fiskal dan Peningkatan Peran Ekonomi UMKM.

Burhan, F. (2020). Bisnis Anjlok Akibat Pandemi Corona, UMKM Bisa Uabh Strategi Usaha

Dinas Koperasi dan UKM Daerah Istimewa Yogyakarta. (2020). Program Pemulihan Ekonomi Melalui

Optimalisasi UMKM Pada Era New Normal di Daerah Istimewa Yogyakarta

Febrantara, D. (2020). Bagaimana Penanganan UKM di Berbagai Negara Saat Ada Pandemi Covid-19 Hadiwardoyo, W. (2020). Kerugian Ekonomi Nasional Akibat Pandemi Covid-19 
Hanoatubun, S. (2020). Dampak Covid-19 terhadap Prekonomian Indonesia. EduPsyCouns: Journal of Education, Psychology and Counseling, 2(1), 146-153

Kemenkes. (2020). Surat Edaran No. HK.02.01/MENKES/335/2020 tentang Protokol Pencegahan Penularan COVID-19 di Tempat Kerja Sektor Jasa dan Perdagangan (Area Publik) dalam Mendukung Keberlangsungan Usaha. Jakarta

Kemenkop-UKM. (2018). Perkembangan Data Usaha Mikro, Kecil, Menengah (UMKM) dan Usaha Besar (UB).

Kemenkop-UKM. (2020). Menkop dan UKM Paparkan Skema Pemulihan Ekonomi KUKM di Masa dan Pasca COVID-19

Maftuchan, A. (2020). Policy Brief 21-Program Tunai di Era COVID-19: Bantuan Tunai Korona atau Jaminan Penghasilan Semesta

Media Indonesia.Com. (15 Mei 2020). Kemenkop Ajak Pelaku UMKM dan Masyarakat Taat Protokol Kesehatan. Media Indonesia

Pakpahan, A. K. (2020). COVID-19 dan Implikasi Bagi Usaha Mikro, Kecil, dan Menengah. Jurnal IImiah Hubungan Internasional, 59-64

Peraturan Pemerintah Republik Indonesia Nomor 7 Tahun 2021 Tentang Kemudahan, Pelindungan, dan Pemberdayaan Koperasi Dan Usaha Mikro, Kecil, Dan Menengah

Prasetyo, A., \& Huda, M. (2019). Analisis Peranan Usaha Kecil dan Menengah Terhadap Penyerapan Tenaga Kerja di Kabupaten Kebumen. Fokus Bisnis: Media Pengkajian Manajemen dan Akuntansi, 18(1), 26-3

Susilawati, S., Falefi, R., \& Purwoko, A. (2020). Impact of COVID-19's Pandemic on the Economy of Indonesia. Budapest International Research and Critics Institute (BIRCI-Journal): Humanities and Social Sciences, 3(2), 1147-1156 